Jurnal Hukum Mimbar Justitia

Fakultas Hukum Universitas Suryakancana

Vol. 4 No. 2 - Desember 2018, hlm. 156-166.

ISSN: 2477-5681 (Cetak), ISSN: 2580-0906 (Online)

Open Access at: https://jurnal.unsur.ac.id/jmj

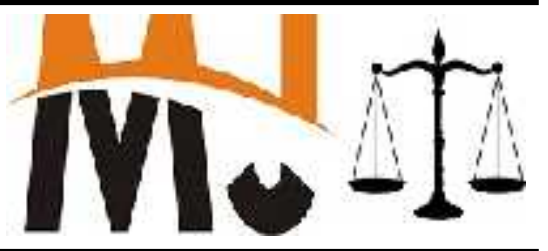

\title{
BEZIT AND NARCOTICS POWER ACCORDING TO LAW NO. 35 OF 2009 CONCERNING NARCOTICS
}

\author{
Ahmad Hunaeni Zulkarnaen \\ Universitas Suryakancana \\ Email : ahmadhzul@gmail.com
}

Masuk: September 2018 Penerimaan: Oktober 2018 Publikasi: Desember 2018

\begin{abstract}
ABSTRAK
Narkotika adalah zat atau obat yang memiliki potensi merusak kesehatan, yang kemudian produksi, distribusi dan konsumsinya kemudian diatur dalam Undang-undang No. 35 Tahun 2009 tentang Narkotika (UUN). Penyalahgunaan narkotika adalah tindakan memiliki, membeli, menjual, menguasai dan memakai narkotika secara illegal. Penyalahgunaan narkotika secara illegal termasuk kejahatan luar biasa (extra ordinary crime) dengan ancaman sanksi pidana yang sangat berat sampai dengan pidana mati. melihat beratnya sanksi kepada penyalahguna narkotika dan kurang jelasnya pengertian "menguasai" dalam UUN, maka tentu saja perlindungan hukum terhadap tersangka penyalahguna narkotika harus ditanggapi secara serius, khususnya kepada orang yang tanpa sepengetahuannya dan tanpa ada maksud memiliki telah menguasai/membawa narkotika.
\end{abstract}

Kata Kunci: Bezit; Narkotika; Penyalahgunaan Narkotika.

\section{ABSTRACT}

Narcotics are substances or drugs that have the potential to damage health, which then production, distribution and consumption are then regulated in code No. 35 of 2009 concerning Narcotics (UUN). Drug abuse is the act of possessing, buying, selling and using narcotics. Narcotics abuses are considered to be high-level crime (extraordinary crime), and the sanctions for such crimes are very serious, starting from rehabilitation to capital punishment. seeing the severity of sanctions on narcotics abusers and the unclear definition of "possessing" in UUN, of course legal protection of suspected drug abusers must be taken seriously. Especially for those possessing/carrying narcotics without their knowledge.

Keywords: Bezit; Narcotics; Drug Abuse.

\section{INTRODUCTION}

Aristoteles said that humans are

Zoon Politicon, namely social beings, who are predestined to always live in a society and interact with one another, which is what distinguishes humans 
from animals. The process of gathering, communicating and interacting is referred to as association. Relationships are not always positive, sometimes there are parties who try to plunge someone into negative things, such as narcotics. Narcotics are substances that can cause certain influences for those who consume them, these effects are in the form of refraction, loss of pain, stimulation, enthusiasm and hallucinations. With the emergence of hallucinatory effects this causes community groups, especially among teenagers, to want to use Narcotics even though they do not suffer anything. This is what causes the occurrence of narcotics abuse (drugs). The danger of using Narcotics if it is not in accordance with the regulations is the existence of addiction/drug dependence (addiction). ${ }^{1}$

Of its kind, narcotics are divided into three groups, with different levels of danger, each group I (one) Narcotics, potentially dangerous and at high risk of causing dependence, prohibited from being used for therapy (treatment);

1 Agustin dan Rinny, 2014, Persepsi Masyarakat Tentang Sosialisasi Bahaya Narkoba Di Kelurahan Sidomulyo Kecamatan Samarinda Ilir Kota Samarinda, (Persepsi, bahaya narkoba, sosialisasi), EJournal Ilmu Komunikasi, hlm. 294-308.
Group II narcotics (two), which have high potential to cause dependence but can still be used for therapy as a last resort; Group III narcotics (three) which have the lowest potential can cause dependence and can be used for therapy. ${ }^{2}$

Based on the aspects of the subject, Narcotics abusers are classified as: addicts, dealers, and dealers. Drugs dealer does not have a clear definition in Law no. 35 of 2009 concerning Narcotics, but if referring to Article 1 paragraph (18), the city can be classified as a person or group of people who control or capitalize on illegal drug trafficking. Distributors also do not have a clear definition in the Narcotics Law, but dealers can be classified as people or couriers who play a role in channeling and submitting Narcotics/Psychotropics from the city to consumers/addict. ${ }^{3}$ While based on Article 1 number 13, Law No. 35 of

Mudji Waluyo, 2007, Pedoman Pelaksanaan P4GN Melalui Peran Serta Kepala Desa/Lurah Babinkamtibnas dan PLKB di tingkat desa/kelurahan, BNN, Jakarta, hlm. 48.

3 Lihat : Tri Jata Ayu Pramesti, apakah bandar narkotika sama dengan pengedar, http://www.hukumonline.com /klinik/detail/ It56cf393b411a0/apakahbandar-narkotika-sama-dengan-pengedar, diakses pada 20-09-2018, pukul 15:00. 
2009 concerning Narcotics (UUN), addicts are people who consume and are in a state of dependence on narcotics both physically and psychologically.

Narcotics abuse has a very bad effect which can lead to addiction which results in dependence. According to Hawari, this happens because of the drug traits that cause it:

1. A desire that is not overpowering the substance in question and if necessary in any way to obtain it;

2. The tendency to add doses or doses with body tolerance;

3. Psychological dependence, that is, when the use of a stopped substance will cause psychiatric symptoms, such as anxiety, anxiety, depression, and the like;

4. Physical dependence that is when the use of substances is stopped will cause physical symptoms. ${ }^{4}$

The dangerous potential then raises UUN, which is where the contents mostly forbid narcotics abuse, such as consuming, distributing, trading, possessing and mastering.

4 Azmiyati, Siti Riza, 2014, Gambaran penggunaan NAPZA pada anak jalanan di Kota Semarang. Jurnal Kesehatan Masyarakat (KEMAS), Vol. 9 No. 2, hlm. 137143.
Article 111 to 148 Law No. 35 of 2009 specifically regulates sanctions on narcotics abuse. these sanctions start from the obligation of rehabilitation, imprisonment, fines, and capital punishment.

As is stated in Article 111 up to Article 148 of Law no. 35 of 2009 concerning Narcotics regulates that for anyone without rights or against the law to plant, maintain, possess, store, control, or provide Narcotics both group I (one), II (two), and III (three), are threatened with criminal imprisonment, fines and capital punishment. The main problem in UUN is the understanding of narcotics control as regulated in articles 111, 112, 117, 122, 129, 147 UUN, these articles do not provide clear understanding of the phrase "mastery" so that the understanding becomes blurred and has multiple interpretations, which become the problem is whether a person is subject to criminal sanctions as regulated in UUN, even though the person actually does not realize he has mastered narcotics, even in him there is no intention at all to have it? or can someone be considered master of narcotics only by mastering the 
Ahmad Hunaeni Zulkarnaen

Jurnal Hukum Mimbar Justitia

Vol. 4 No. 2 - Desember 2018

narcotics materially, even though the narcotics formally does not necessarily belong to him? narcotics ?, From here the author tries to examine the meaning of the word "mastering narcotics" so that it can provide clarity in the conditions of how someone is considered to have mastered narcotics illegally.

\section{RESULT AND DISCUSSIONS}

The definition of mastery of narcotics can be associated with bezit in civil law, namely a birth condition, where a person controls an object as if it were his own, which by law is protected, by not questioning the ownership of the object which is actually in whom. Bezit words come from the words "zitten" so that letterlijk means "to occupy." The form of bezit is required to have two elements, namely the power of an object and the willingness to possess the object. Bezit must be distinguished "detentie", where a person controls an object based on a legal relationship with a person controlling an object based on a legal relationship with another person, is the owner or bezitter of that thing. In a "detentor" (for example a tenant) it is considered that the willingness to possess the object in control is not there. ${ }^{5}$ Responding to Subekti opinion, the willingness or intention factor is very important in determining whether someone can be called mastering narcotics, because not everyone who controls narcotics has the willingness to have it.

Bezit is an actual condition, a person controls an object, both movable and immovable objects, but in a formal juridical manner the object is not necessarily his. This means that bezitter only controls objects materially, while in formal juridical things belong to someone else. The elements listed in bezit, are as follows:

1. There is a bezitter;

2. The existence of legal objects;

3. Material mastery;

4. Bezitter gets protection;

5. No matter who the object belongs to. ${ }^{6}$

Responding to Salim opinion, then someone can be considered to master narcotics by only mastering the

Subekti, 2001, Pokok-pokok Hukum Perdata, Intermasa, Jakarta, hlm. 63.

6 Salim HS, 2003, Pengantar Hukum Perdata Tertulis (BW), Sinar Grafika, Jakarta, hlm. 105. 
narcotics materially, even though the narcotics formally is not necessarily his.

The way people get bezit, different according to objects. Whether the object moves or does not move. Does the acquisition occur with the help of someone who has mastered it first, or not with the help of another (original acquisition or originair by taking or "occupation"). ${ }^{7}$

How to get bezit with occupatio is also called the method of originair (original). This means obtaining an item/object independently without the help of people who check first. This can be fixed on moving and immovable objects. The acquisition of bezit in the traditio way is to obtain the object with the help of the first one. Obtained from the hands of the old bezitter to the hands of the new bezitter. ${ }^{8}$

Bezit on a moving object, obtained original by taking the item from its original place so that it can be seen clearly or expressly the intention to start being in someone's bezit. Bezit on an object that moves with the help of

7 Subekti, 2001, Pokok-pokok Hukum Perdata..., Loc.Cit.

8 Masjchoen, Sri Soedewi, Tanpa Tahun, Hukum Badan Pribadi, Yayasan Badan Penerbit Gadjah Mada, Yogyakarta, hlm. 6263. another person (operand), obtained by the handover of goods from the hands of the old bezitter to the hands of the new bezitter. ${ }^{9}$ Meaning that the possession of narcotics can occur by means of transportation, that is, from the seller to the buyer, or by taking it directly from the source, such as cannabis plantations.

When relating it to narcotics mastery the author tends to agree more with Salim opinion that it does not question the ownership of objects to determine the control of goods, because not all goods authorities have the willingness to own these items (for example narcotics couriers). Save the author, all people who have narcotics must have mastered narcotics. All people who buy narcotics must have mastered and possessed narcotics, but mastering narcotics does not necessarily have narcotics, because it could be that the narcotics belongs to someone else. From here the problem is not mastering or not mastering narcotics, but illegal or not mastery of narcotics. Factor of will, intention, inner attitude or intentional (dollus) very plays an important role in

$9 \begin{aligned} & \text { Subekti, 2001, Pokok-pokok Hukum } \\ & \text { Perdata..., Loc.Cit. }\end{aligned}$ 
Ahmad Hunaeni Zulkarnaen

Jurnal Hukum Mimbar Justitia

Vol. 4 No. 2 - Desember 2018

determining whether someone controls narcotics illegally or not.

Intentionality is closely related to criminal liability. Speaking of criminal liability, there are two views, namely a monistic view, among others stated by Simon who formulated "strafbaarfeit as" eene strafbaar gestelde, onrechtmatige, met schuld in verband staande handeling van een torekeningvatbaar person (an act which by the law is threatened with punishment, contrary to law, carried out by someone who is guilty and that person is deemed responsible for his actions)". ${ }^{10}$ According to the flow of monism, the elements of the religious organization include both the element of action, which is commonly called the objective element, and the element of maker which is commonly called the subjective element. Therefore, mixed elements of action with the element of its maker, it can be concluded that the structure of the crime is the same as the terms of criminal imposition, so as if it

10 Muladi dan Dwidja Priyatno, 2010, Pertanggungjawaban Pidana Korporasi, Kencana Prenada Media Group, Jakarta, hlm. 61. is assumed that if there is a crime, then the perpetrator can be convicted. ${ }^{11}$

Based on the explanation above, then criminal acts do not stand alone, new criminal acts are meaningful when there is criminal responsibility. This means that every person who commits a crime does not necessarily have to be convicted. Criminal liability due to the subjective element of the offender is of course very closely related to the factor of the presence or absence of errors that contain elements of violating the law for actions or actions committed by the perpetrators. The end result can be in the form of a statement that no element is found to be unlawful in his actions so that there is no error from the culprit, but it can also be found an element of breaking the law in his actions but there is no mistake from the culprit. ${ }^{12}$

In the Indonesian Criminal Code there are no provisions that formulate an understanding of intentions. The meaning of deliberation can only be

11 Septa Candra, 2013, Pembaharuan Hukum Pidana; Konsep Pertanggungjawaban Pidana Dalam Hukum Pidana Nasional Yang Akan Datang, Jurnal Cita Hukum, Vol. I No. 1 Juni, hlm. $39-56$.

12 I Gede Somonita, I Made Suwitra, I Made Sepud, 2017, Pemalsuan Dokumen Dalam Pendaftaran Hak Atas Tanah Di Denpasar, Jurnal Hukum Prasada, Vol. 4, No. 2 September, hlm. 67-79. 
Ahmad Hunaeni Zulkarnaen

Jurnal Hukum Mimbar Justitia

Vol. 4 No. 2 - Desember 2018

found in the teachings of criminal law (doctrine). In general intentions can be given meaning as intentions which are potentially manifested in the form of actions or in other words intentions are the intention to do or not take actions such as those prohibited or required by law. In the doctrine there are 3 (three) forms of intentions, namely:

1. Opzet als oogmerk (intentional purpose);

2. Opzet bij zekerheids bewustzijn (intentionality as certainty)

3. Opzet bij mogelijkheids bewustzijn (intentionality as a possibility). ${ }^{13}$

In the draft Indonesian Criminal Code draft began to include the notion of intentional and negligence in Chapter 2 concerning Criminal Acts and Criminal Liability. In the Chapter mentioned: "Whoever commits a crime by knowing and wanting it, he commits the act intentionally". That Indonesian Positive Criminal Law does not have a single provision that defines intentions and omissions. The formulation of these two things is only found in the draft

13 P.A.F. Lamintang, 1984, Dasar-dasar Untuk Mempelajari Hukum Pidana yang Berlaku di Indonesia, Sinar Baru, Bandung, hlm. 295.
Criminal Code Draft in Chapter 2 Book I. $^{14}$

There are some countries in the Criminal Code formulating the definition of intentions, for example: Article 59 paragraph 2 and 3 of the Thai Criminal Code which states: 1) To do an act intentionally is to do an act consciously and at the same time the doer desired or could have foressen the effect of such doing; 2) If the doer does not know the facts constituting the offence, it can not be deemed. That he desired or could have foreseen the effect of such doing.

Article 7 paragraph 1 of the Polish Criminal Code states: An offence is intentional when the perpetrator has the intent to commit the prohibited act, that is he wills it commission or foresseing the possibility of commiting it he reconciles himself to this. ${ }^{15}$

In other words, based on the definitions expressed in the Thai Criminal Code and the Polish Criminal Code, the mastery of narcotics without

14 I Made Minggu Widyantara, Kesengajaan dan Kealpaan (Suatu Tinjauan Dari Sudut Perbandingan Hukum Pidana Indonesia Dengan Hukum Pidana Asing), Kertha Wicaksana, Vol. 21 No. 1 Januari, hlm. 1.

15 Barda Namawi Arief, 1990, Perbandingan Hukum Pidana, Rajawali Pers, Jakarta, hlm. 93. 


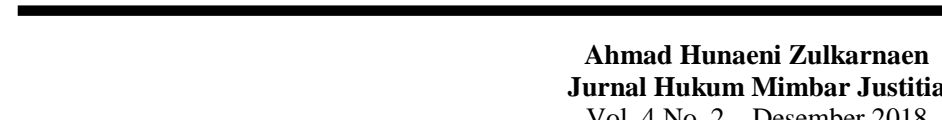

Vol. 4 No. 2 -Desember 2018

the knowledge of the
perpetrators/creators cannot be
categorized as intentional. Because the
perpetrator does not want to carry or
possess the narcotics, or can be estimated/know in advance the consequences of illegal acts of carrying narcotics.

Intentionality which is the inner attitude of the offender is closely related to mistakes. In criminal law, according to Moeljatno someone's mistakes and negligence can be measured by whether the criminal offender is capable of being responsible, that is if the action contains 3 (three) elements, namely:

1. Conducting a criminal act (against the law);

2. Above a certain age is able to be responsible:

3. Has a form of error in the form of intentions (dolus) and negligence (culpa). ${ }^{16}$

Non-criminal principle without error, which in Dutch is known as "geen straf zonder schuld". German "Keine Straf Ohne Schuld". In English criminal law this principle is known as in Latin which reads: actus non facit reum, nisi

16 Moeljatno, 2002, Asas-Asas Hukum Pidana, Rineka Cipta, Jakarta, hlm. 164. mens sit rea (the act does not make a person guilty, unless the mind is guilty). We cannot find this principle in the language of the Criminal Code, as is the case with the principle of legality. This principle is the principle contained in unwritten law. ${ }^{17}$

The Principle of No Criminal Without Mistakes or Principle of Error means that a person who has committed an act contrary to the applicable criminal law regulations cannot be convicted because of the absence of errors in his actions. This principle is manifested in Article 6 paragraph (2) of Law No. 4 of 2004 concerning Judicial Power, which determines that: "No one can be sentenced to criminality, except if the court is due to legal evidence, which has the conviction that someone who is deemed to be responsible, has been guilty of an act charged with him". 18

In short, the principle "geen straf zonder schuld" does not require the punishment of someone who in fact has

17 Moeljatno, 1983, Perbuatan Pidana dan Pertanggungjawaban Dalam Hukum Pidana, Bina Aksara, Jakarta, hlm. 3-4.

18 A.A. Ngurah Wirajaya, 2013, Asas Tiada Pidana Tanpa Kesalahan (Asas Kesalahan) Dalam Hubungannya Dengan Pertanggungjawaban Pidana Korporasi, kertha Negara, Vol. 01 No. 03 Mei, hlm. 1. 
indeed violated criminal regulations, will remain without error. The principle is said even though it is not contained in the Criminal Code, but in general people think that principle is reasonable and should be in criminal law. In connection with this principle $\mathbf{R}$.

Achmad S. Soema Dipraja stated that the principle "geen straf zonder schuld" is now not a principle that is outside the law, because it has been contained in Article 6 paragraph (2) of Law No. 14 of 1970 concerning Basic provisions of Judicial Power (see also in Article 6 paragraph (2) of Law No. 4 of 2004 concerning Judicial Power), determining: "No one can be convicted, except because a legitimate means of proof according to the law has a conviction that someone who is deemed to be responsible has been guilty of an act alleged against him".

An official explanation of the article includes the following:

Article 5 to Article 8.

This all guarantees human rights that get protection in the state based on the Pancasila. ${ }^{19}$

19 Dipradja, R. Achmad., S. Soema, 1983, Beberapa Tinjauan Tentang Hukum Pidana Dan Hukum Acara Pidana, Armico, Bandung, hlm. 21.
A non-criminal adage without errors in criminal law is usually used in the sense of no criminal without subjective errors or irreproachable errors. However, in criminal law, people cannot talk about mistakes without any improper conduct. Therefore, the principle of error is interpreted as noncriminal without objective inappropriate actions which can be harmed to the perpetrators. The principle of error is a fundamental principle in criminal law, so the fundamentals are so pervasive and echoing in almost all teachings in criminal law. ${ }^{20}$

Based on the description above, so that the enforcement of criminal law, especially in the narcotics sector is in line with the principle of Geen Straf Zonder Schuld (no crime without error), narcotics mastery classification should have considered the wrongdoing or intentional aspects of the perpetrator.

\section{CONCLUSION}

That narcotics control is a situation where someone controls/holds narcotics, but in a formal way the

20 E.Ph.R. Sutorius, Wonosutanto, 1987, Bahan Penataran Hukum Pidana Angkatan I: Het Schuldbeginsel/Opzet En De Varianten Daarvan, FH-UNDIP, Semarang, hlm. 1. 


\section{Ahmad Hunaeni Zulkarnaen \\ Jurnal Hukum Mimbar Justitia \\ Vol. 4 No. 2 - Desember 2018}

narcotics is not necessarily his. This means that the person only masters narcotics materially, whereas in formal juridical things belong to someone else.

That criminal liability in narcotics control is determined by the legal or not mastery of narcotics, therefore the intention factor, inner attitude, or mistake of the perpetrator is very important in determining the legality of mastering narcotics.

Whereas if the perpetrator has never realized that he has mastered/carried narcotics, then the intentional element of the narcotics control becomes non-existent.

\section{DAFTAR ISI}

\section{A. Buku}

Barda Namawi Arief, 1990, Perbandingan Hukum Pidana, Rajawali Pers, Jakarta.

Dipradja, R. Achmad., S. Soema, 1983, Beberapa Tinjauan Tentang Hukum Pidana Dan Hukum Acara Pidana, Armico, Bandung.

E.Ph.R. Sutorius, Wonosutanto, 1987, Bahan Penataran Hukum Pidana Angkatan I: Het Schuldbeginsel/Opzet En De Varianten Daarvan, FH-UNDIP, Semarang.
Masjchoen, Sri Soedewi, Tanpa Tahun, Hukum Badan Pribadi, Yayasan Badan Penerbit Gadjah Mada, Yogyakarta.

Moeljatno, 1983, Perbuatan Pidana dan Pertanggungjawaban Dalam Hukum Pidana, Bina Aksara, Jakarta.

Moeljatno, 2002, Asas-Asas Hukum Pidana, Rineka Cipta, Jakarta.

Mudji Waluyo, 2007, Pedoman Pelaksanaan P4GN Melalui Peran Serta Kepala Desa/Lurah Babinkamtibnas dan PLKB di tingkat desa/kelurahan, BNN, Jakarta.

Muladi dan Dwidja Priyatno, 2010, Pertanggungjawaban Pidana Korporasi, Kencana Prenada Media Group, Jakarta.

P.A.F. Lamintang, 1984, Dasar-dasar Untuk Mempelajari Hukum Pidana yang Berlaku di Indonesia, Sinar Baru, Bandung.

Salim HS, 2003, Pengantar Hukum Perdata Tertulis $(B W)$, Sinar Grafika, Jakarta.

Subekti, 2001, Pokok-pokok Hukum Perdata, Intermasa, Jakarta.

\section{B. Peraturan Perundang- Undangan}

Undang-Undang Dasar Republik Indonesia Tahun 1945. 
Ahmad Hunaeni Zulkarnaen

Jurnal Hukum Mimbar Justitia

Vol. 4 No. 2 - Desember 2018

Undang-Undang Nomor 1 Tahun 1946 Tentang Kitab Undang-Undang Hukum Pidana.

Kitab Undang-Undang Hukum Perdata.

Undang-Undang Nomor 35 Tahun 2009 tentang Narkotika.

\section{Jurnal.}

A.A. Ngurah Wirajaya, 2013, Asas Tiada Pidana Tanpa Kesalahan (Asas Kesalahan) Dalam Hubungannya Dengan Pertanggungjawaban Pidana Korporasi, kertha Negara, Vol. 01 No. 03 Mei.

Agustin dan Rinny, 2014, Persepsi Masyarakat Tentang Sosialisasi Bahaya Narkoba Di Kelurahan Sidomulyo Kecamatan Samarinda Ilir Kota Samarinda, (Persepsi, bahaya narkoba, sosialisasi), EJournal Ilmu Komunikasi.

Azmiyati, Siti Riza, 2014, Gambaran penggunaan NAPZA pada anak jalanan di Kota Semarang. Jurnal Kesehatan Masyarakat (KEMAS), Vol. 9 No. 2.
I Gede Somonita, I Made Suwitra, I Made Sepud, 2017, Pemalsuan Dokumen Dalam Pendaftaran Hak Atas Tanah Di Denpasar, Jurnal Hukum Prasada, Vol. 4, No. 2 September.

I Made Minggu Widyantara, Kesengajaan dan Kealpaan (Suatu Tinjauan Dari Sudut Perbandingan Hukum Pidana Indonesia Dengan Hukum Pidana Asing), Kertha Wicaksana, Vol. 21 No. 1 Januari.

Septa Candra, 2013, Pembaharuan Hukum Pidana; Konsep Pertanggungjawaban Pidana Dalam Hukum Pidana Nasional Yang Akan Datang, Jurnal Cita Hukum, Vol. I No. 1 Juni.

\section{Internet dan Lain-lain.}

Lihat : Tri Jata Ayu Pramesti, apakah bandar narkotika sama dengan pengedar, http://www.hukumonline.com /klinik/detail/ 1t56cf393b411a0/apakah-bandarnarkotika-sama-dengan-pengedar, diakses pada 20-09-2018, pukul 15:00. 